\title{
The Application of Genetic Algorithm in Solving Traveling Salesman Problem
}

\author{
Elis Ratna Wulan', Neulis Pipit Apriani² \\ \{elis_ratna_wulan@uinsgd.ac.id ${ }^{1}$, matematika@uinsgd.ac.id² \\ Mathematics Department, Science and Technology Faculty, UIN Sunan Gunung Djati Bandung, \\ Indonesia ${ }^{1,2}$
}

\begin{abstract}
Traveling Salesman Problem (TSP) is one form of optimization problem with easy concept, but complicated if solved conventionally. The purpose of TSP is to build an optimal routes, with the rules of each city to be visited by salesmen and the cities are visited only exactly once, the trip begins and ends in the city early. To build the optimal routes, in this study using genetic algorithm. In the example case there are 4 cities that must be traversed by the salesman, that city A, B, C, and D with the trip starts from the city A and ends in city A as well. So obtained the optimal route that is [A D B C] with minimum distance that is $19 \mathrm{~km}$.
\end{abstract}

Keywords: Traveling Salesman Problem (TSP), Optimization, Genetic Algorithm

\section{Introduction}

Traveling Salesman Problem (TSP) is a form of optimization problem with a simple concept, but complicated if conventionally solved. This TSP is a matter of finding the optimal route for a salesman who must visit several cities exactly once with trips starting and ending in the same city. The problem faced is how to build an optimal route by considering these rules, so that the shortest route is obtained.

Several algorithms have been developed to solve TSP problems such as Brute Force Algorithm, Greedy Algorithm, Genetic Algorithm, Branch and Bound Algorithm. To solve the Traveling Salesman Problem, Genetic Algorithms will be applied to obtain optimal solutions. That is, because the Genetic Algorithm is one alternative algorithm that can be used, with a fast process and gives the desired results.

Genetic Algorithm is a metaheuristic search algorithm that works based on the mechanism of natural selection and natural genetics. The main idea behind this algorithm is to choose the best individuals from an individual population and perform recombination between individuals to generate new individuals who are expected to be better than the previous individual. In this research, the application of Genetic Algorithms was carried out on Traveling Salesman Problem. 


\section{Literature Review}

\subsection{Assignment Problem}

Assignment problems are problems that have only one objective of optimization, namely maximizing or minimizing a resource (income, cost, distance or time) used to complete the job. The assignment problem is a special case of linear programming that allocates resources to activities on a one-to-one basis. Thus, every source (employee, machine) only has one task in an activity (work, location or event). As a result, there will be a cost $c_{i j}$ that is related to the employee $i(i=1,2, \ldots, m)$ which does the job $j(j=1,2, \ldots, n)$. Thus the objective of the assignment problem is to assign each job accordingly to the employee so that the total expenditure of resources (income, cost, distance or time) to complete all jobs can be optimized [2].

To solve the assignment problem, we have to meet the following assumptions [2]:

1. The number of employees and the number of assignments are the same (this number is expressed by $n$ ).

2. Each employee is assigned only one job.

3. Each job is carried out by only one employee.

4. There is a cost $c_{i j}$ fee that is correspond to the employee $i(i=1,2, \ldots, m)$ and which does the job $j(j=1,2, \ldots, n)$.

5. The objective of problem solving is to determine how to do all the $n$ in order to minimize the total cost.

The general description of the assignment problem is represented in the following matrix [3]:

\section{Machine}

$$
\text { Job }\left[\begin{array}{cccc}
c_{11} & c_{12} & \cdots & c_{1 n} \\
c_{21} & c_{22} & \cdots & c_{2 n} \\
\vdots & \vdots & \vdots & \vdots \\
c_{m 1} & c_{m 2} & \cdots & c_{m n}
\end{array}\right]
$$

If there is a job $i$ where $i=1,2, \ldots, m$ is assigned to the machine $j$ where $j(j=1,2, \ldots, n)$, then there is a cost of $c_{i j .}$. Mathematically, the assignment model can be stated as follows [2]:

$$
x_{i j}=\left\{\begin{array}{l}
1, \text { if } \mathrm{i} \text { th } \mathrm{job} \text { is assigned to } \mathrm{j} \text { th machine } \\
0, \quad \text { if } \mathrm{i} \text { th job is assigned to } \mathrm{j} \text { th machine }
\end{array}\right.
$$

Thus, this assignment model is [2]:

Objective Function:

Subject to:

$$
\operatorname{Min} \mathrm{Z}=\sum_{i=0}^{m} \sum_{j=0}^{n} c_{i j} x_{i j}
$$

$$
\begin{aligned}
& \sum_{\substack{j=0 \\
m}}^{n} x_{i j}=1, \quad i=1,2, \ldots, m \\
& \sum_{i=0}^{m} x_{i j}=1, \quad j=1,2, \ldots, n
\end{aligned}
$$




\subsection{Traveling Salesman Problem}

In 1800, Irish mathematician William Rowan Hamilton and British mathematician Thomas Penyngton raised the mathematical problem that was the forerunner of the Traveling Salesman Prolem (TSP). The TSP is presented in the form of a game called Icosian Hamilton which requires players to complete the game by connecting 20 travel points using only certain paths. Furthermore, this is known in discrete mathematics called Hamilton Circuit theory [4].

The emergence of a general form of TSP was first studied by a mathematician Karl Menger in Vienna and Harvard in 1930. Then this problem was published by Hassler Whitney and Merrill Flood at Princenton. Detailed discussion of the relationship between Menger and Whitney, and the development of TSP as a study topic is presented in Alexander Schrijver's paper entitled "On the history of combinatorial optimization (till 1960)" [4].

According to Manggolo et al. Traveling salesman problem is an issue of optimization to find the shortest path for salesmen who want to visit several cities. Traveling salesman problems are known as one of the optimization problems that attract the attention of mathematicians and especially computer scientists because TSP is simple to define but is so complicated to solve [4].

Things to be considered in the TSP case is the journey of the salesman starting from the beginning of the city to the next to the city and finally going back to the initial city. However, the rule is that every city other than the initial city can only be visited exactly once. The problem faced is how to build an optimal route by considering these rules in order to obtain a minimum total path so that it will have an impact on saving transportation costs [4].

The problem faced in this case is not simple, because there are many combinations of route flows that might occur along with the number of cities that will be visited and also we have to pay attention to the rules that apply. A simple form of TSP representation into a graph can be seen in Figure 1. In the picture there are seven city points that must be visited by salesman and one square point which is defined as the initial route and the final route in constructing the route. In route search, first we have to know the distances between cities. However, if the distances are unknown, the distance can be calculated based on the coordinates of each point. See Figure $2[4]$.

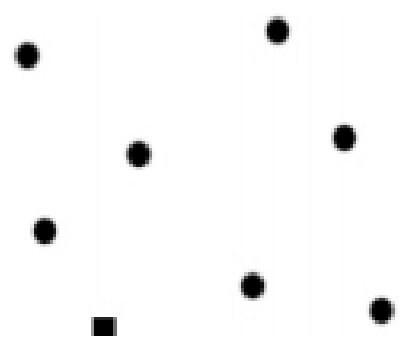

Figure 1. City point that will be crossed

After the distance connecting each city is known, then the shortest route can be searched by trying all combinations and adding up the distance from the combination thus the route as shown in Figure 2 is obtained as follows [4]. 


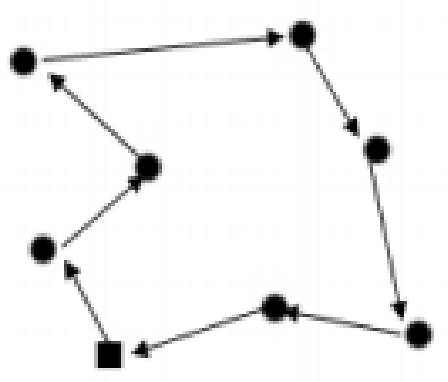

Figure 2. The Shortest Route

There are various approaches and algorithms that can be used to solve this problem including Brute Force Algorithm, Greedy Algorithm, Annealing Simulation, Genetic Algorithm, Branch and Bounch Algorithm and others [4].

\subsection{Combinatorial Optimization}

Combinatorial optimization is part of optimization in applied mathematics and computer science and related to research operations, algorithm theory, and complexity calculation theory. This combinatorial optimization looks for maximum or minimum values depending on the problem in question. The algorithm of combinatorial optimization is used to solve problems that are quite complex and have a large enough scope [6].

Combinatorial problems are problems that have a finite set of feasible solutions. Although in principle the solution to this problem can be obtained with complete enumeration, complex problems require time that cannot be practically accepted [19]. One form of the optimization problem is the Traveling Salesman Problem (TSP). The TSP as a problem that is simple to understand but complicated to solve (get the optimal solution). Thus the large number of cities involved, finding solutions for selecting the best route to visit $n$ cities will be increasingly complicated. Therefore we need a program that can complete the task. Approach algorithms in various literatures have been successfully applied to various combinatorial problems, such as planning and scheduling of production in the manufacturing industry. Although the optimum solution is not obtained, a solution that is close to the optimum can be obtained in a relatively short time and can be accepted practically [6].

\subsection{Vehicle Routing Problem (VHR)}

Kallehauge et.al [20] defines the problem of m-TSP as a variation of TSP, where there are $m$-salesmen visiting a number of cities and each city can only be visited by exactly one salesman. Each salesman starts from a depot and at the end of the journey must also return to the depot. The m-TSP problem is often referred to as the Vehicle Routing Problem, where a city is associated with a demand or customer and each vehicle used for travel is considered to have a certain capacity. The total amount of demand on a route must not exceed the capacity of the vehicles assigned to pass the route. This makes VRP sometimes referred to as Capacitated Vehicle Routing Problem (CVRP). Just like the TSP problem, in VRP there is also a depot, where each vehicle must depart and return to the depot. In VRP, aside from aiming to minimize the total distance or total transportation costs, it can also minimize the number of vehicles used 
$(m)$. The VRP problem aims to determine a set of vehicle trips with a minimum total cost, which starts and ends at the depot, each customer is visited exactly once, the total demand carried by each vehicle does not exceed the vehicle's capacity $Q$, and the cost of each vehicle does not exceed upper limit $L$ specified [8].

Genetic Algorithm is a search algorithm based on the mechanism of natural and genetic selection. Genetic algorithm is one algorithm that is very appropriate to be used in solving complex optimization problems, which are difficult to do by conventional methods. Genetic algorithms were first introduced by John Holland (1975) from the University of Michigan. John Holland states that every problem in the form of adaptation (natural or artificial) can be formulated into genetic terminology [10].

The emergence of Genetic Algorithms is inspired by theories in biology, so many biology terms and concepts are used in Genetic Algorithms. As the name implies, the processes that occur in genetic algorithms are the same as what happens in biological evolution [11].

The nature of genetic algorithms is to look for possibilities from prospective solutions to get optimal solutions in problem solving. The scope of all feasible solutions, i.e. various objects among suitable solutions, is called the search space. Each point in the search space presents a viable solution. Every feasible solution can be marked by its fitness value. The solution sought in genetic algorithms is the point (one or more) between feasible solutions in the search space [11].

\section{Results and Discussion}

\subsection{Genetic Algorithm}

Genetic Algorithm is a search algorithm based on the mechanism of natural and genetic selection. Genetic algorithm is one algorithm that is very appropriate to be used in solving complex optimization problems, which are difficult to do by conventional methods. Genetic algorithms were first introduced by John Holland (1975) from the University of Michigan. John Holland states that every problem in the form of adaptation (natural or artificial) can be formulated into genetic terminology [10].

The emergence of Genetic Algorithms is inspired by theories in biology, so many biology terms and concepts are used in Genetic Algorithms. As the name implies, the processes that occur in genetic algorithms are the same as what happens in biological evolution [11].

The nature of genetic algorithms is to look for possibilities from prospective solutions to get optimal solutions in problem solving. The scope of all feasible solutions, i.e. various objects among suitable solutions, is called the search space. Each point in the search space presents a viable solution. Every feasible solution can be marked by its fitness value. The solution sought in genetic algorithms is the point (one or more) between feasible solutions in the search space [11].

\subsection{Numerical Example}

There are 4 cities that a salesman will pass through, namely Cities A, B, C, and D. The journey starts from city A and ends at city A as well. Distances between cities are shown in the graph in Figure 3 [18]: 


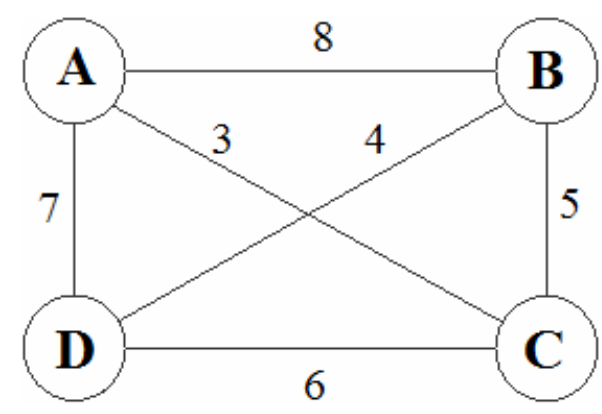

Figure 3. Travel Routes

The TSP problem in Figure 3 will be solved using genetic algorithms. The criteria for stopping are determined in advance if after one generation the highest fitness value is not changed. The highest fitness value was chosen, as a condition, because it represents the closest distance that is sought in this TSP problem.

After completion process using Genetic Algorithms, the fitness value of all chromosomes is as follows (in Table 1):

Table 1. Chromosome Fitness Values After 1 Generation

\begin{tabular}{lll}
\hline Chromosome & Total Distance & Fitness \\
\hline 1 & 21 & 0,0476190476 \\
2 & 19 & 0,0526315789 \\
3 & 26 & 0,038465385 \\
Total Fitness & & $\mathbf{0 , 1 3 8 7 1 2 1 6 5 9 0 4 7 6}$ \\
\hline
\end{tabular}

Thus, the iteration is stopped because it matches the termination criteria, where after one generation the highest fitness value is unchanged. Therefore, it can be concluded that the shortest distance to visit all cities is $19 \mathrm{~km}$, with the optimal route [A D B C].

\section{Conclusions}

Using genetic algorithms to solve the Traveling Salesman Problem, the first stage is to generate an initial population, which in one population consists of several individuals. The number of individuals in the population according to the type of TSP used. Chromosomes are formed from the arrangement of genes which is the route that a salesman must travel, with a journey starting at city A and ending at city A as well.

Each chromosome is calculated the distance of the route and its fitness value, to obtain the highest fitness value with the distance of the closest route. Next, a selection is done by calculating the relative fitness value and the cumulative fitness value first, after which random numbers are raised from 0 to 1 as many as the number of individuals, in finding these random 
numbers using Excel, so that a new population is obtained. The new population was carried out crossover using a crossover order and a new population was obtained again. Then, the new population from the crossover is mutated using inversion mutation, this is because every initial and final gene on the chromosome must not change, where the salesman must start from city A and end in city A as well. From the mutation process a new population is obtained. The last process of one generation of genetic algorithms is replacement of generations, this new generation is the result of crossover and mutation processes. The new population is calculated back to the distance of the route and its fitness value, to obtain the highest fitness value with the distance of the closest route that does not change, therefore the iteration is stopped and the optimal route is obtained [A D B C] with a distance of $19 \mathrm{~km}$. For further research, Branch and Bound Algorithm can be used in its solution.

\section{References}

[1] J. J. Siang, Riset Operasi dalam Pendekatan Algoritma, Edisi 2. Yogyakarta : CV. ANDI OFFSET,(2014)

[2] F.S.Hillier and G.J.Lieberman. Introduction To Operations Research, 8 th Edition. Yogyakarta: Andi, (2008)

[3] G. N. P.Suwandira, R.Indryani, and I.A.R.Widhiawati, Optimasi Biaya Pekerjaan Aspal Hot Mix Dengan Model Penugasan (Assignment Model) Pada Proyek Jalan Di Bal, Jurnal ilmiah Teknik Sipil, Vol. 10, No. 1, January 2006, Hal. 12-18, (2006).

[4] M. D. A. C. Hasibuan, Lusiana, Pencarian Rute Terbaik Pada Travelling Salesman Problem (TSP)Menggunakan Algoritma Genetika pada Dinas Kebersihan dan PertamananKota Pekanbaru, Jurnal STMIK Amik Riau, Vol. 1, No. 1, (2015).

[5] D. Sudrajat, Pengoptimalan Masalah Pemograman Linier Dengan Menggunakan Metode CrissCross, Literature Study, UIN Sunan Gunung Djati Bandung, (2015).

[6] R. Nababan, Enumerasi Parsial Untuk Masalah Optimisasi Kombinatorial, Thesis,USU, Medan,(2008).

[7] P. Toth and D. Vigo, The Vehicle Routing Problem, Philadelpia: Siam, (2002).

[8] D. Tarigan, Pemodelan Vehicle Routing Problem Terbuka Dengan Keterbatasan Waktu, Thesis, USU, Medan (2008).

[9] C. S. Hutasoit, S. Susanty, and A. Imran, Penentuan Rute Distribusi Es Balok Menggunakan Algoritma Nearest Neighbour dan Local Search, Jurnal Online Institut Teknologi Nasional, Vol. 02, No. 02, (20140.

[10] L. Bochar and B. Radi, A New Approach to Treath the Selective Travelling Salesman Problem, International Mathematical Forum, Vol.11, No. 16, (2016).

[11] Muliadi, Pemodelan Algoritma Genetika Pada Sistem Penjadwalan Perkuliahan Prodi Ilmu Komputer Universitas Lambungmangkurat, Kumpulan jurna Ilmu Komputer (KLIK), Vol.01, No.01, September (2014).

[12] E. N. Fitriana, Implementasi Algoritma Genetika Dengan Teknik Kendali Logika Fuzzy Untuk Mengatasi Travelling Salesman Problem Menggunakan Matlab, Thesis, Mathematics Department, UNNES, Semarang, (2014).

[13] R. Masutiawati, Optimalisasi Minimum-Weight Spanning Trees Dengan Menggunakan Algoritma Genetika, Literature Study, UIN Sunan Gunung Djati Bandung, (2010).

[14] S. Lukas, T. Anwar, and W. Yuliani, Penerapan Algoritma Genetika Untuk Travelling Salesman Problem Dengan Menggunakan Metode Order Crossover Dan Insertion Mutation, Seminar Nasional Aplikasi Teknologi Informasi, Yogyakarta, 18 Juni (2005).

[15] Y. Arkeman, K. B. Seminar, and H. Gunawan, Algoritma Genetika. Bogor : PT Penerbit IPB Press, (2012).

[16] E. Suhartono, Optimisasi Penjadwalan Mata Kuliah Dengan Algoritma Genetika, INFOKAM, No. II, Th. XI, September (2015). 
[17] S. C. Sumarta, Analisis Algoritma Genetika Tanpa Operasi Crossover Pada Kasus Travelling Salesman Problem Dengan Metode 2 Tahap Mutasi, Jurnal Tematika, Vol. 3, No. 2, September (2015). [18] D. T. Wiyanti, Algoritma Optimisasi Untuk Penyelesaian Travelling Salesman Problem, Jurnal Informatika, Vol. 11, No.1, Juli (2013).

[19] Lee, J. A First Course in Combinatorial Optimization. Cambridge University Press. (2004)

[20] Kallehauge, B., Larsen, J., and Madsen, O.B.G. Lagrangean Duality applied on vehicle routing with time windows - Experimental results. Technical report, IMM-REP-2001-9, Technical University of Denmark (2001) 